\title{
Manfaat Aktivitas Fisik Teratur Terhadap Perbaikan Fungsi Kognitif Pasien dengan Mild Cognitive Impairment
}

\author{
Rina Amtarina*
}

\begin{abstract}
Regular physical activity have a positive impact on improving cognision for elderly with Mild Cognitive Impairment (MCI). Our aim was to answer a clinical question of the effect exercise for improving cognition. We conducted an Evidence Based Case Report (EBCR) of exercise effects on cogitive outcomes in elderly with MCI. We did electronic searching on database PubMed, Cochrane Library, ScienceDirect, National Electronic Library for Health, Bandolier, Trip Database and SumSearch for 2004-2014, using keywords and combination of search term(s): AND, OR, brackets. The search found three articles with various strength of evidence. Most of them could prove that regular activity have positive impact on improving cognision.
\end{abstract}

Keywords: elderly, physical activity, cognition, memory, mild cognitive impairment

Aktivitas fisik yang teratur memiliki manfaat terhadap kesehatan pada semua golongan usia. Akhir-akhir ini, banyak peneliti dan klinisi menaruh perhatian terhadap manfaat aktivitas fisik dalam memperbaiki kognisi pada orang lanjut usia yang mengalami mild cognitive impairment (MCI). ${ }^{1}$ Seseorang dengan kondisi MCI memiliki risiko tinggi untuk berkembang menjadi demensia alzheimer dengan rata-rata konversi sebesar 50\% dalam 2-3 tahun dan meningkat $60-100 \%$ dalam 510 tahun. $^{2-6}$ Manfaat aktivitas fisik yang teratur seperti jalan kaki, Tai chi atau aerobic dikatakan bisa membantu meningkatkan fungsi kognitif dan memperlambat onset MCI menjadi demensia. ${ }^{1,7-12}$

Berdasarkan defenisi dari WHO (World Health Organization), aktivitas fisik untuk orang lanjut usia meliputi aktivitas fisik yang menyenangkan atau rekreasi, transportasi (misal jalan kaki dan bersepeda), pekerjaan (jika masih bekerja), tugas rumah tangga, permainan, olahraga, latihan fisik terencana dalam konteks sehari-hari, keluarga dan aktivitas dalam komunitas. ${ }^{13,14}$ Menurut Institute of Medicine and The American College of Sports Medicine (ACSM), aktivitas fisik adalah pergerakan badan yang dihasilkan dari kontraksi otot skelet dan meningkatkan pengeluaran energi. Latihan fisik atau exercise lebih merujuk pada aktivitas fisik yang

\footnotetext{
* Penulis untuk korespondensi :KJF Ilmu Kedokteran Jiwa FKUR, Email : $\underline{\text { amtarina@gmail.com }}$
}

terencana, terstruktur, dan gerakan berulang untuk memperbaiki atau memelihara kebugaran tubuh. Berikut adalah ringkasan jenis aktivitas fisik berdasarkan WHO dan ACSM: ${ }^{14}$

Tabel 1. Defenisi dan tipe aktivitas fisik. ${ }^{14}$

\begin{tabular}{|c|c|c|}
\hline Source & $\begin{array}{l}\text { Type of physical } \\
\text { activity }\end{array}$ & $\begin{array}{l}\text { Recommendati } \\
\text { on }\end{array}$ \\
\hline \multirow[t]{4}{*}{ WHO } & Aerobic physical activity & $\begin{array}{l}150 \text { min of moderate } \\
\text { intensity throughout } \\
\text { the week, or } 75 \text { min of } \\
\text { vigorous intensity or } \\
\text { an equivalent } \\
\text { combination (of } \\
\text { moderate and vigorous } \\
\text { intensity activity }\end{array}$ \\
\hline & $\begin{array}{l}\text { Balance } \\
\text { enhancement/prevention of } \\
\text { falls }\end{array}$ & $\begin{array}{l}3 \text { or more days per } \\
\text { week }\end{array}$ \\
\hline & $\begin{array}{l}\text { Muscle strengthening } \\
\text { activities }\end{array}$ & $\begin{array}{l}\text { Should be done } \\
\text { involving major } \\
\text { muscle groups, on } 2 \\
\text { or more days a week }\end{array}$ \\
\hline & $\begin{array}{l}\text { Aerobic exercise training } \\
\text { (AET) refers to exercises in } \\
\text { which the body's large } \\
\text { muscles move in a } \\
\text { rhythmic manner for } \\
\text { sustained periods }\end{array}$ & $\begin{array}{l}\text { Frequency at least } 2 \\
\text { days/week }\end{array}$ \\
\hline \multirow[t]{2}{*}{$\begin{array}{l}\text { ACSM } \\
\text { (American } \\
\text { College } \\
\text { Sports } \\
\text { Medicine) }\end{array}$} & $\begin{array}{l}\text { Resistance exercise training } \\
\text { is exercise that cause } \\
\text { muscles to work or hold } \\
\text { against an applied force or } \\
\text { weight }\end{array}$ & $\begin{array}{l}\text { Frequency at least } 2 \\
\text { days/week }\end{array}$ \\
\hline & $\begin{array}{l}\text { Flexibility exercise refers to } \\
\text { activities designed to } \\
\text { preserve or extend range of } \\
\text { motion (ROM) around a } \\
\text { joint } \\
\text { Balance training refers to a } \\
\text { combination of activities } \\
\text { designed to increase lower } \\
\text { body strength and reduce } \\
\text { the likelihood the of falling }\end{array}$ & $\begin{array}{l}\text { Frequency at least } 2 \\
\text { days/week }\end{array}$ \\
\hline
\end{tabular}


Pada literatur lain mengelompokkan jenis latihan fisik menjadi jenis aerobic exercise (lari, bersepeda, jalan cepat) dan jenis anaerobic exercise (stretching, toning, yoga). ${ }^{15}$ Suatu penelitian terhadap orang lanjut usia menyebutkan aktivitas fisik yang teratur dapat meregulasi sejumlah faktor pertumbuhan seperti BDNF (Brain Derived Neurotrophic Factor) yang memegang peran dalam neuroproteksi dan synaptic plasticity. ${ }^{16,17}$ Serum BDNF yang tinggi dapat meningkatkan volum hippocampus yang merupakan area belajar dan memori. ${ }^{14}$ Pada penelitian tersebut disebutkan aerobic exercise intensitas tinggi selama enam bulan dapat memperbaiki kognisi. ${ }^{8,17}$ Aktivitas jalan kaki intensitas sedang yang teratur juga dapat memperbaiki fungsi kognitif terutama aspek memori. ${ }^{18}$

Pada umumnya MCI tidak diberikan terapi secara farmakologis. Hal ini menyebabkan aktivitas fisik teratur dapat disarankan sebagai salah satu terapi nonfarmakologis. Pertanyaan klinis yang muncul mengenai apakah ada manfaat aktivitas fisik yang teratur terhadap perbaikan fungsi kognitif pada pasien lanjut usia dengan MCI. Penulis melalui Evidence Based Case Report berusaha untuk menjawab pertanyaan tersebut.

\section{KASUS}

Seorang laki-laki, usia 71 tahun, pensiunan AURI bagian perbekalan datang ke Poliklinik Psikiatri di Pusat Geriatri Terpadu dengan keluhan penurunan fungsi kognitif. Ia mulai sering lupa seperti lupa tempat meletakkan dompet, kunci mobil, hari, tanggal dan lupa lokasi parkir mobil. Keluhan ini tidak hanya disadari pasien tetapi juga disadari oleh anak-anaknya sehingga anak-anaknya menyarankan pasien untuk berobat. Keluhan sering lupa ini telah dirasakan pasien sejak 2 tahun yang lalu. Pasien sudah lama pensiun dan kegiatan banyak diisi dengan berkebun. Hobinya masih terpelihara. Aktivitas seperti mandi, makan dan berpakaian masih dapat dilakukan dengan baik. Pada hasil pemeriksaan tidak didapatkan psikopatologi yang bermakna. Pemeriksaan Mini Mental State Examination (MMSE) menunjukkan skor MMSE 24, Montreal Cognitive Assessment versi Indonesia (MOCA-INA) 19 dan Clinical Dementia Rating (CDR) 0,5. Pasien didapatkan kondisi MCI. Saat itu pasien tidak diberikan psikofarmaka dan dianjurkan kontrol enam bulan kemudian. Pasien dianjurkan untuk melatih fungsi kognitif seperti mengerjakan teka-teki silang (TTS) atau bermain catur. Menurut pasien, sebenarnya kedua hal tersebut bukanlah hobinya tetapi ia akan melakukannya jika hal tersebut dapat menolong memperbaiki fungsi kognitifnya. Pasien mengatakan ia memiliki hobi berolahraga seperti senam ataupun jalan pagi namun sejak pensiun, tidak pernah lagi dilakukan.

Penulis pernah mendengar bahwa aktivitas fisik dapat membantu memperbaiki fungsi kognitif. Oleh karena itu, penulis berupaya mencari buktibukti yang mendukung informasi mengenai pengaruh aktivitas fisik dalam memperbaiki fungsi kognitif.

\section{FORMULASI PERTANYAAN KLINIS}

Apakah aktivitas fisik yang teratur dapat bermanfaat membantu memperbaiki fungsi kognitif pada pasien usia lanjut dengan $\mathrm{MCI}$ ?

Pernyataan klinis tersebut diformulasikan dalam bentuk PICO sebagai berikut: ${ }^{19,20}$

$\mathrm{P}($ Patient $) \quad$ : Pasien lanjut usia dengan MCI

I (Intervention) : Aktivitas fisik teratur

C (Comparation) : Tidak ada kontak, aktivitas normal, edukasi

$\mathrm{O}$ (Outcome) : Perbaikan fungsi kognitif

\section{METODE PENELUSURAN BUKTI}

Penelusuran dilakukan pada database PubMed, ScienceDirect, Cochrane Library, National Electronic Library for Health, Bandolier, Trip Database, dan SumSearch, menggunakan kata kunci yang disusun berdasarkan konsep Boolean operators sebagai berikut: ("mild cognitive impairment") AND (exercise* OR physical training* OR physical activity* OR motor activity* OR physical fitness*) AND (cognitive function* OR cognitive ability* OR memory* OR cognition*) AND (elderly* OR aged* OR aging* OR older* OR geriatr*) 
Setelah dilakukan pembatasan serta penyaringan terhadap judul dan abstrak pada hasil penelusuran, didapatkan tiga jurnal yang sesuai dengan pertanyaan klinis yaitu:

1. Gates $\mathrm{N}$ et al. The effect of exercise training on cognitive function in older adults with MCI: a meta analysis of randomized controlled trials. Am J Geriatr Psychiatry. 2013

2. Suzuki T et al. Effects of multicomponent exercise on cognitive function in older adults with amnestic MCI: a randomized controlled trial. BMC Neurology. 2012.

3. Nagamatsu et al. Physical activity improves verbal and spatial memory in older adults with probable mild cognitive impairment: a 6-month randomized controlled trial. Journal of Aging Research. 2013.

Proses selanjutnya adalah telaah kritis pada jurnal tersebut yang mencakup validitas (validity), hasil (importance), dan kemamputerapan (applicability). ${ }^{19,20}$ Detil mengenai proses penelusuran pada database dan telaah kritis, ditampilkan pada lampiran.

\section{HASIL PENELUSURAN}

1. Gates $\mathrm{N}$ et al. The effect of exercise training on cognitive function in older adults with Mild Cognitive Impairmen: a meta analysis of randomized controlled trials. 2013

Penelitian ini merupakan systematic reviewmeta analysis yang bertujuan untuk mengetahui manfaaat latihan fisik terhadap perbaikan fungsi kognitif pada pasien dengan kondisi MCI. Latar belakang penelitian ini adalah adanya bukti epidemiologis hubungan antara aktivitas fisik dengan kognitif dan menurunkan risiko demensia. Penelitian yang masuk dalam meta analisis ini adalah randomized controlled trial (RCTs) sebanyak 14 penelitian dengan jumlah total sampel 1695 orang dengan kondisi MCI. Pencarian data penelitian ini didapat dari Medline, EMBASE, CINAHL, PEDro, SPORTSDICUS, PSychInfo, PubMed. Pencarian dibatasi pada kata kunci tertentu, pada manusia, menggunakan bahasa Inggris, usia 65 tahun keatas, peer reviewed dan RCT. Hasil keluaran yang diharapkan adalah manfaat aktivitas fisik terhadap perbaikan fungsi kognitif pada pasien dengan MCI. ${ }^{21}$
Pada meta analisis ini, dipilih penelitian yang memenuhi kriteria inklusi yang telah ditetapkan. Populasi yang memenuhi kriteria inklusi adalah orang dengan MCI yang ditentukan secara klinis berdasarkan kriteria yang ada atau memiliki skor MMSE 24-28. Intervensi berupa aktivitas fisik sesuai dengan defenisi dari ACSM yaitu aktivitas fisik yang terencana, terstruktur dan berulang, memiliki tujuan akhir atau menengah, perbaikan atau pemeliharaan kebugaran fisik. Latihan dengan durasi kurang dari empat minggu dikeluarkan dari penelitian ini. Tidak ada batasan pada modalitas, dosis, intensitas,atau supervisi tetapi jenis latihan harus ditentukan secara spesifik. Intervensi multimodal dimasukkan dalam kriteria inklusi selama dapat dinilai efek dari aktivitas fisik tersebut (sebagai contoh aktivitas fisik dikombinasi dengan obat versus pemberian obat tunggal). Grup kontrol adalah grup yang tidak ada kontak, tidak ada pengobatan, berada dalam daftar tunggu, latihan gerakan semu atau sedang menjalani perawatan alternatif. Keluaran dinilai melalui tes neuropsikologis kognitif yang divalidasi dan diukur pada saat baseline dan follow up. ${ }^{21}$

Semua RCT menyertakan peserta yang sehat secara fisik tanpa ada gerakan atau kondisi jantung yang menghambat latihan fisik. Tidak ada kondisi neurologis seperti stroke atau parkinson. Modalitas intervensi yang digunakan pada masing-masing RCT bervariasi mulai dari latihan aerobic intensitas sedang dan intensitas tinggi, jalan kaki intensitas rendah, resistance training, latihan campuran keseimbangan dengan aerobic, latihan koordinasi dan keseimbangan, intervensi dengan intensitas rendah seperti Tai chi, kombinasi jalan kaki intensitas rendah dengan latihan tangan-muka untuk lanjut usia yang rapuh. Dosis dan intensitas latihan bervariasi antara 30-90 menit per sesi, dua hingga empat sesi per minggu. Durasi intervensi bervariasi antara 6-52 minggu. Aktivitas fisik dilakukan dalam grup atau individual atau kombinasi. ${ }^{21}$

Sebagai kontrol bervariasi termasuk kunjungan sosial atau tidak ada kontak, program edukasi, aktivitas normal atau rekreasi. Termasuk juga gerakan semu seperti stretching, fleksibilitas atau aerobic intensitas rendah. Keluaran dinilai dari MMSE (Mini Mental State Examination), ADASCog (Alzheimer's Disease Assessment Scale Cognitive Subscale), CAMCOG (Cambridge 
Cognition Examination) dan WAIS-R (Weschler Adult Intelligence Scale Revised). Hasil meta analisis ini menunjukkan sembilan dari 14 RCT yang ada, secara bermakna memiliki manfaat terhadap fungsi kognitif sedikitnya pada satu keluaran. latihan fisik dilaporkan memperbaiki verbal fluency, kognisi global, fluid intelligence, fungsi eksekutif dan memori pada beberapa penelitian. Secara keseluruhan, hanya $8 \%$ keluaran yang bermakna dari seluruh RCT. ${ }^{21}$

Effect size untuk area fungsi eksekutif tidak dapat digabungkan disebabkan pengulangan pada beberapa penelitian yang mencantumkan tes fungsi eksekutif yang beragam. Begitu juga effect size pada area immediate dan delayed memory tidak dapat digabungkan disebabkan heterogenitas yang tinggi $\left(\mathrm{I}^{2}=82 \%\right)$. Jenis isolated aerobic training memberikan perbaikan fungsi kognitif global yang ditemukan pada tiga penelitian. Jenis isolated resistance training bermakna pada memori tetapi tidak untuk fungsi eksekutif. Pada intervensi multimodal dan jenis low intensity walking tidak memberikan manfaat yang bermakna. Jenis single Tai chi memberikan efek yang bermakna pada kognisi global dan visual attention. ${ }^{21}$

Efek latihan aerobic sangat terbatas untuk verbal fluency dan tidak ada efek untuk fungsi eksekutif. Efek yang bermakna terdapat pada fungsi kognisi secara global. Dari dua RCT didapatkan bahwa jenis high intensity resistance training memiliki manfaat terhadap perbaikan memori. Sebaliknya jenis lower intensity resistance training dikombinasi dengan modalitas latihan fisik lainnya tidak memberikan hasil yang meyakinkan. Kesimpulan akhir dari meta analisis ini sebagian besar hasil keluaran yang didapatkan tidak bermakna secara statistik (92\% penelitian). Hal ini memberikan data tidak ada bukti yang kuat secara bermakna bahwa aktivitas fisik secara teratur bermanfaat dalam memperbaiki fungsi kognitif. ${ }^{21}$

2. Suzuki $\mathrm{T}$ et al. Effects of multicomponent exercise on cognitive function in older adults with amnestic MCI: a randomized controlled trial. 2012

Penelitian ini adalah penelitian randomized controlled trial berlatar belakang data epidemiologis bahwa aktivitas fisik seperti jalan kaki dapat menurunkan risiko demensia. Berdasarkan literatur sebelumnya diketahui bahwa latihan fisik yang multikomponen dapat memperbaiki fungsi kognitif. Penelitian ini untuk bertujuan untuk membuktikan hal itu. Penelitian ini dilakukan selama 12 bulan dengan membandingkan latihan fisik multikomponen dengan grup kontrol yang diukur pada saat baseline. Peserta berusia 65 tahun keatas, memenuhi kriteria MCI sesuai dengan kriteria Petersen. Kriteria eksklusi adalah peserta dengan CDR 0, 1, 2, 3, memiliki riwayat gangguan neurologi, psikiatri, jantung atau penggunaan donepezil dan gangguan ADL (Activity Daily Living). ${ }^{22}$

Sebagai intervensi adalah latihan fisik dibawah arahan fisioterapis selama 90 menit/hari, dua hari dalam seminggu dengan total 80 kali selama 12 bulan. Grup yang mendapat latihan fisik tersebut terdiri atas 16-17 orang peserta. Setiap latihan dimulai dengan sepuluh menit pemanasan dan diikuti dengan 20 menit latihan kekuatan otot. Latihan dilanjutkan dengan latihan aerobic, postural balance retraining, dan dual task training selama 60 menit. Pada akhir latihan, dilakukan circuit training termasuk stair stepping, endurance walking dan berjalan di papan keseimbangan. Pada grup kontrol mendapat tiga kali kelas edukasi mengenai promosi kesehatan selama 12 bulan. Mereka tidak menerima informasi mengenai aktivitas fisik, olahraga dan kesehatan kognitif. ${ }^{22}$

Keluaran dari penelitian ini berupa fungsi kognitif yang diukur saat baseline, setelah 6 bulan dan setelah 12 bulan. Alat ukur fungsi kognitif yang digunakan adalah MMSE untuk mengukur fungsi kognitif umum. WMS-LM I dan II (Weschler Memory Scale Logical Memory) untuk mengukur fungsi memori logika. DSC (Digit Symbol Coding) untuk menilai kecepatan pengolahan ingatan. Verbal fluency diukur dengan LVFT (Letter verbal Fluency Test) dan CVFT (Category Verbal Fluency Test). SCWT (Stroop Color and Word Test) untuk mengukur fungsi eksekutif. Hasil dari penelitian ini menunjukkan aktivitas fisik dengan multikomponen selama 12 bulan dapat memperbaiki fungsi kognitif pasien usia lanjut dengan MCI. Efek positif terlihat pada fungsi kognitif umum, memori segera dan kemampuan berbahasa. ${ }^{22}$ 
3. Nagamatsu et al. Physical activity improves verbal and spatial memory in older adults with probable mild cognitive impairment: a 6-month randomized controlled trial. Journal of Aging Research. 2013.

Penelitian ini merupakan penelitian RCT yang bertujuan untuk melihat efikasi dari latihan fisik sebagai strategi intervensi memperbaiki memori pada pasien yang memiliki MCI. Latar belakang penelitian ini adalah karena adanya ketertarikan terhadap aktivitas fisik sebagai strategi intervensi alternatif selain terapi farmakologis. Desain penelitian ini adalah single blinded-RCT selama 26 minggu. Kriteria peserta adalah usia 70-80 tahun, tinggal sendiri, skor MMSE e" 24/30, skor MoCA Â 26/30, memiliki keluhan gangguan memori, skor Lawton and Brody instrumental activities of daily leaving e" $6 / 8$, visual acuity 20/40 dengan atau tanpa kacamata, dan mendapat izin untuk mengikuti aktivitas fisik. Kriteria eksklusi adalah pasien dengan kondisi medis yang menjadi kontraindikasi dilakukannya aktivitas fisik, telah mengikuti secara teratur resistance training dan aerobic training selama 6 bulan sebelumnya, memiliki penyakit neurodegenerative/stroke, memiliki gangguan psikiatri, memiliki demensia, sedang menjalani terapi pengganti estrogen dan kesulitan berbicara dan mengerti bahasa Inggris. ${ }^{23}$

Level aktivitas fisik ditentukan melalui kuisioner Physical Activities Scale for the Elderly (PASE). GDS (Geriatric Depression Scale) digunakan untuk menyaring depresi. Functional Comorbidity Index untuk memperkirakan tingkat morbiditas dan untuk menilai aktivitas sehari-hari digunakan the Lawton and Brody Instrumental Activities of Daily Living Scale. Untuk verbal memory dan learning dinilai menggunakan Rey Auditory Verbal Learning Test (RAVLT). Spatial memory diperiksa melalui computerized task developed in house. Keseimbangan umum dan pergerakan diperiksa menggunakan The Short Physical Performance Battery. Pengambilan sampel dilakukan secara acak dan samar, dikelompokkan kedalam tiga grup yaitu grup yang mendapat resistance training, aerobic training dan balance and tone (BAT). ${ }^{23}$

Latihan dimulai satu bulan setelah pemeriksaan baseline dengan pelatih yang telah mendapat pelatihan tambahan dari peneliti. Latihan selama 60 menit terdiri atas 10 menit pemanasan, 40 menit inti latihan dan 10 menit pendinginan. Data dianalisis menggunakan IBM SPSS Statistics versi 20. Hasil penelitian ini menyebutkan bahwa seluruh peserta tidak ditemukan perbedaan secara bermakna pada level aktivitas fisik saat baseline. Pada jenis latihan fisik berupa aerobic exercise, resistance training dan BAT dua kali seminggu selama enam bulan secara bermakna memperbaiki verbal memory dan learning. ${ }^{23}$

\section{PEMBAHASAN}

Penelitian Gates et al merupakan systematic review meta analisis. Berdasarkan level of evidence menurut Oxford Centre for Evidence-Based Medicine 2011, berada pada level satu. ${ }^{24}$ Meta analisis ini juga melakukan telaah validitas terhadap keempatbelas RCT yang disertakan dan hasilnya keempat belas RCT memiliki kualitas tingkat sedang. Kebanyakan RCT yang ada memiliki sampel dengan jumlah terlalu kecil sehingga power penelitian rendah untuk mendeteksi small effect. Hanya tiga studi yang melakukan follow up setelah intervensi 6 minggu, 24 minggu, 12 bulan dan 18 bulan. Tidak terdapat blinded assessors pada 11 $\mathrm{RCT}$, kurangnya therapist blinded sebanyak 13 $\mathrm{RCT}$, tidak adanya intention to treat analysis pada 7 RCT dan informasi yang tidak cukup mengenai data dasar antara grup pada 8 RCT.

Kelemahan meta analisis ini adalah membatasi pencarian yang hanya menggunakan artikel berbahasa Inggris, kata kunci tertentu, judul dan abstrak tertentu menyebabkan pembatasan cakupan dari seluruh penelitian lain yang mungkin potensial. Terbatasnya jumlah RCT, heterogenitas dari RCT yang ada, pengulangan penelitian dengan menggunakan tes fungsi kognitif yang beragam menyebabkan jumlah sampel lebih besar dari aslinya.

Studi Suzuki et al merupakan studi RCT yang memiliki metodologi yang cukup baik. Berdasarkan level of evidence menurut Oxford Centre for Evidence-Based Medicine 2011, berada pada level dua. ${ }^{24}$ Antara grup kontrol dan grup intervensi pada saat baseline memiliki karakteristik yang tidak ada perbedaan secara bermakna sehingga meminimalisir 
terjadinya bias. Studi ini mencantumkan waktu follow up setelah dilakukan intervensi. Studi ini juga memiliki assessor blinded, randomisasi pengambilan sampel, menggunakan reliabilitas alat ukur yang valid dan keluaran didapatkan pada lebih dari $85 \%$ subjek.

Kelemahan studi Suzuki tidak menyebutkan alokasi subjek yang disamarkan. Tidak ditemukan care provider blinded dan subject blinded. Data untuk perhitungan importance dan applicability tidak tercantum. Penelitian ini juga memiliki keterbatasan yaitu jumlah sampel yang sedikit, tidak mencantumkan informasi mengenai intention to treat analysis. Penelitian ini juga tidak melakukan evaluasi terhadap faktor risiko lain terkait penurunan fungsi kognitif dan risiko terjadinya demensia pada seseorang sehingga dapat menimbulkan bias penelitian.

Studi Nagamatsu et al merupakan studi single blinded-randomized trial yang memiliki metodologi yang cukup baik. Berdasarkan level of evidence menurut Oxford Centre for Evidence-Based Medicine 2011, berada pada level dua. ${ }^{24}$ Pada saat baseline memiliki karakteristik level aktivitas fisik yang tidak ada perbedaan secara bermakna diantara ketiga grup. Studi ini mencantumkan waktu follow up setelah dilakukan intervensi. Pada studi terdapat randomisasi pengambilan sampel dan menggunakan reliabilitas alat ukur yang valid.

Kelemahan studi Nagamatsu adalah tidak menyebutkan investigator blinded dan instructor blinded. Penelitian ini juga tidak mencantumkan data yang lengkap untuk perhitungan importance dan appicability. Penelitian ini memiliki jumlah sampel yang sedikit dan tidak mencantumkan data mengenai intention to treat analysis. Dalam penelitian ini juga tidak terdapat keterangan mengenai grup kontrol.

\section{APLIKASI BUKTI}

Pada pasien ini memiliki keluhan mengenai penurunan daya ingat. Keadaan ini merupakan hal yang penting bagi pasien. Keterbatasan terapi secara farmakologis untuk kondisi pasien mendorong untuk mengembangkan terapi non farmakologis. Salah satunya adalah aktivitas fisik secara teratur. Pasien memiliki hobi melakukan senam dan jalan kaki namun sudah tidak lagi dilakukan semenjak pensiun. Sesuatu hal yang sangat baik bila pasien melakukan hal yang disenangi sembari memperbaiki fungsi kognitifnya.

Setelah melakukan penelusuran bukti, pasien memiliki karakteristik yang sama dengan subjek studi sehingga hasil studi dapat diterapkan pada pasien. Terdapat hasil yang beragam mengenai manfaat aktivitas fisik yang teratur terhadap fungsi kognitif. Studi yang pertama memiliki heterogenitas tinggi sehingga hasilnya tidak ada manfaat aktivitas fisik teratur terhadap fungsi kognitif. Studi kedua dan ketiga membuktikan adanya manfaat aktivitas fisik teratur. Namun tidak menyediakan data perhitungan untuk importance dan applicability.

Pilihan aktivitas fisik teratur untuk membantu memperbaiki fungsi kognitif masih dapat diterapkan pada pasien. Hal ini didukung teori dan penelitian lain yang menunjukkan aktivitas fisik yang teratur dapat membantu perbaikan fungsi kognitif. Pada pasien perlu diberikan penjelasan tentang adanya perbaikan klinis yang mungkin dapat dicoba pada pasien, walaupun tidak bermakna secara statistik. Aktivitas fisik yang dilakukan dapat diterapkan pada pasien dengan arahan Dokter bagian Rehabilitasi Medik dan fisioterapis di seting rawat jalan. Jenis Aktifitas fisik yang dapat dicobakan berupa isolated aerobic training, isolated resistance training, tai chi, balance and tone dan aktivitas fisik dengan multikomponen. Keteraturan dalam menjalankan aktivitas fisik diperlukan untuk mendapatkan hasil yang maksimal.

\section{KESIMPULAN}

Penelitian mengenai manfaaat aktivitas fisik secara teratur terhadap perbaikan fungsi kognitif masih beragam hasilnya. Studi meta analisis yang dilakukan memiliki heterogenitas yang tinggi sehingga menunjukkan hasil yang tidak bermakna. Kedua studi RCT dalam EBCR ini menunjukkan hasil yang positif tetapi tidak didukung data importance dan applicability. Meskipun demikian, aktivitas fisik yang teratur masih dapat diterapkan karena didasarkan pada teori dan penelitian lain yang menunjukkan manfaatnya terhadap fungsi kognitif. Aktivitas fisik tersebut dapat memperbaiki fungsi kognitif secara global, verbal fluency, fluid 
intelligence, fungsi eksekutif dan fungsi memori. Aktivitas fisik harus dilakukan secara teratur untuk mendapatkan hasil yang maksimal.

\section{DAFTAR PUSTAKA}

1. Lautenschlager NT, Cox K, Kurs AF. Physical activity and mild cognitive impairment and alzheimer's disease. Curr Neurol Neurosci Rep. 2010; 10: 352-358.

2. Law LLF, Barnett F, Yau MK, Gray MA. Effects of combined cognitive and exercise intervention on cognition in older adult with or without cognitive impairment: a systematic review. Ageing Resc Reviews. 2014; 15: 61-75.

3. Amieva H, Letenneur L, Dartiques JF, Rouch Lerover I, Sourgen C, D'Alchee Biree F et al. Annual rate and predictors of conversion to dementia in subjects presenting mild cognitive impairment criteria defined according to a population-based study. Dement Geriatr Cogn Disord. 2004; 18: 87-93.

4. Petersen RC. Mild cognitive impairment as a diagnostic entity. J Intern Med. 2004; 256(3):183-194.

5. Alzheimer's Association. Mild cognitive impairment. Alzheimer's Association. 2013. Diunduh dari http://www.alz.org/dementia/mildcognitive-impairment-mci pada tanggal 30 April 2014.

6. Kramer AF, Ericksonn KI. Capitalizing on cortical plasticity: influence of physical activity on cognition and brain function. Trends Cogn Sci. 2007; 11(8): 342-348.

7. Ihara M, Okamoto Y, Hase Y, Takahashi R. Association of physical activity with the visuospatial/executive functions of the montreal cognitive assessment in patients with vascular cognitive impairment. J of Stroke and Cerebrovascular Disease. 2013; 22: 7.

8. Baker LD, Frank LL, Schubert KF, Green PS, Wilkinson CW, McTiernan A, Plymate SR, Fishel MA, Watson GS, et al. Effects of aerobic exercise on mild cognitive impairment: a controlled trial. Arch Neurol. 2010; 67(1): 7179.
9. Forbes D, Thiessen EJ, Blake CM, Forbes SC, Forbes S. Exercise programs for people with dementia (Review). Cochrane Collaboration. 2013.

10. Tak Cheng S, Chow PK, Qiang Shong Y, Yu ECS, Chan ACM, Lee TM et al. Mental and physical activities delay cognitive decline in older persons with dementia. Am J Geriatr Psychiatry. 2014; 22: 1 .

11.Teixeira CVL, Gobbi LTB, Corazza DI, Stella F, Costa JLR, Gobbi S. Non pharmacological interventions on cognitive functions in older people with mild cognitive impairment (MCI). Archives of Gerontology and Geriatrics. 2012; 54: 175-180.

12.Carvalho A, Rea IM, Parimon T, Cusack B. Physical activity and cognitive function in individuals over 60 years of age: a systematic review. Clinc Intervention in Aging. 2014; 9: 661-682.

13.WHO. World Health Report 2010 global recommendations on physical activity for health. WHO: Switzerland. 2010.

14.Bamidis PD, Vivas AB, Scyliadis C, Frantzidis C, Klados M, Schlee W, Slountas A, Papageorgiou SG. A review of physical and cognitive interventions in aging. neuroscience and behavioral reviews. 2014. Diunduh dari http://www.elsevier.com pada tanggal 30 april 2014.

15. Miller D, Taler V, Davidson PSR, Messier C. Review: measuring the impact of exercise on cognitive aging: methodological issues. Neurobiol of aging. 2012; 33: 622. Diunduh dari http://www.elsevier.com/locale/neuaging pada tanggal 30 april 2014.

16.Adlard PA, Perreau VM, Cotman CW. The exercise induced expression of bdnf within the hippocampus varies across life span. Nuerobiol Aging. 2005; 26(4): 511-520.

17.Erickson KI, Voss MW, Prakash RS, Basak C, Szabo A, Chaddock L et al. Exercise training increases size of hippocampus and improves memory. PNAS. 2011; 108(7): 3017-3022.

18.Van Uffelen JGZ, Chinapaw MJM, Van 
Mechelen W, Hopman-Rock M. The Effect of walking and vitamin B supplementation on quality of life in community-dwelling adults with mild cognitive impairment: a randomized controlled trial. Br J Sports Med. 2008; 42: 344351.

19.Sastroasmoro S, Ismael S. Dasar-dasar Metodologi Penelitian Klinis, Edisi ke-4. Jakarta. Sagung Seto, 2011.

20.Glasziou P, Del Mar C, Salisbury J. Evidencebased medicine workbook, finding and applying the best evidence to improve patient care. London. BMJ Publishing Group. 2003.

21.Gates N, Singh MAF, Sachdev PS, Valenzuela $M$. The effect of exercise training on cognitive function in older adults with MCI: a meta analysis of randomized controlled trials. Am J Geriatr Psychiatry. 2013; 21: 11.
22. Suzuki T, Shimada H, Makizako H, Doi T, Yoshida D, Tsutsumimoto $\mathrm{K}$ et al. Effects of multicomponent exercise on cognitive function in older adults with amnestic MCI: a randomized controlled trial. BMC Neurology. 2012; 12: 128.

23. Nagamatsu LS, Chan A, Davis JC, Beatti BL, Graf P, Voss MW, et al. Physical activity improves verbal and spatial memory in older adults with probable mild cognitive impairment: a 6-month randomized controlled trial. Journal of Aging Research. 2013.

24. Howick J, OCEBM Levels of evidence working group. The Oxford 2011 Levels of Evidence. Oxford Centre for Evidence-Based Medicine. Diunduh dari http://www.cebm.net/ index.aspx?o=5653 pada tanggal 30 april 2014. 